\title{
EFEKTIVITAS PENAMBAHAN EKSTRAK KURMA TERHADAP KARAKTERISTIK GIZI FRUITGHURT
}

\author{
Desi Arisanti ${ }^{1)}$, Syahmidarni Al Islamiyah ${ }^{2)}$ \\ ${ }^{1,2)}$ Program Studi Teknologi Hasil Pertanian, Politeknik Gorontalo \\ Email : desiarisanti@poligon.ac.id ${ }^{1)}$ \\ Indonesia
}

\begin{abstract}
ABSTRAK
Kurma merupakan buah yang mempunyai kandungan glukosa yang cukup tinggi. Pada umumnya penggunaan kurma digunakan sebagai sebagai penstabil dan pemanis alami pada minuman herbal. Pada penelitian ini penambahan ekstrak kurma diharapkan dapat meningkatkan kandungan nilai gizi minuman probiotik fruitghurt yang berasal dari sari kacang hijau dan kulit semangka. Penelitian ini menggunakan metode Rancangan Acak Lengkap (RAL) dengan tiga perlakuan yaitu konsentrasi ekstrak kurma dengan yaitu $\mathrm{S}_{1}=5 \%, \mathrm{~S}_{2}=15 \%$, $\mathrm{S}_{3}=25 \%$. Hasil penelitian menunjukkan penambahan ekstrak kurma yang berbeda-beda menghasilkan fruitghurt dengan kandungan gizi berupa vitamin $\mathrm{C}$, protein dan total asam laktat yang berbeda-beda pula. Penambahan ekstrak kurma dengan konsentrasi yang berbeda-beda memberikan pengaruh nyata terhadap karakteristik gizi pada fruitghurt yang dihasilkan baik pada kadar vitamin C, kadar protein dan kadar total asam laktat. Karakteristik gizi fruitghurt terbaik berdasarkan kadar tertinggi baik vitamin $\mathrm{C}$ dan kadar protein adalah dengan penambahan ekstrak kurma 25\% $\left(\mathrm{S}_{3}\right)$. Berdasarkan kadar total asam laktat, perlakuan terbaik adalah penambahan ekstrak kurma $15 \%\left(\mathrm{~S}_{2}\right)$.
\end{abstract}

\section{Kata Kunci : Fruitghurt, sari kacang hijau, kulit semangka, esktrak kurma}

\begin{abstract}
Dates are a fruit that has a high enough glucose content. In general, the use of dates is used as a stabilizer and natural sweetener in herbal drinks. In this study, the addition of date palm extracts is expected to increase the nutritional value of fruitghurt probiotic drinks derived from green bean juice and watermelon skin. This study used a completely randomized design method (CRD) with three treatments, namely the concentration of date palm extract, namely $S 1=5 \%, S 2=15 \%, S 3=25 \%$. The results showed that different date extracts produced fruitghurt with vitamin $C$, protein and total lactic acid. The addition of date extracts with different concentrations significantly affected the nutritional characteristics of the resulting fruit gurt on vitamin Clevels, protein levels and total lactic acid levels. The best fruitghurt nutritional characteristics based on the highest vitamin $C$ and protein content are $25 \%$ date extract (S3). Based on the total levels of lactic acid, the best treatment is the addition of $15 \%$ (S2) dates extract.
\end{abstract}

\section{Keywords: Fruitghurt, green bean juice, watermelon ski, date palm extract}

\section{PENDAHULUAN}

Fruitghurt merupakan salah satu minuman diversifikasi dari yoghurt yang terbuat dari sari buah. Beberapa kelebihan fruitghurt yang tidak dimiliki oleh yoghurt pada umumnya yaitu tinggi kandungan antioksidan (Muslimah, 2010). Yoghurt adalah salah satu produk fermentasi susu yang memiliki manfaat untuk kesehatan pencernaan dan dapat mencegah diare (Anjani S, 2013, Yugo JP., 2017). Fruitghurt menggunakan tambahan sari buah dalam proses fermentasinya atau campuran dari beragam jenis sari buah-buahan dengan memanfaatkan kemampuan bakteri asam laktat (BAL). Pada penelitian ini, peneliti memanfaatkan limbah kulit semangka sebagai bahan pembuatan fruitghurt.

Kulit buah semangka merupakan bagian buah yang belum banyak dimanfaatkan (Nusa MI, dkk., 2014 dalam Yugo JP, 2017). Kulit buah semangka banyak manfaatnya dan banyak mengandung nutrisi yang penting bagi kesehatan dan kaya akan berbagai jenis vitamin. Kandungan vitamin kulit semangka tersebut yaitu terdiri dari A, B dan E serta protein. Kulit buah semangka memiliki efek pengobatan untuk berbagai penyakit seperti hipertensi, radang ginjal, sulit buang air kecil dan sembelit. Selain itu, kandungan lainnya yang tidak kalah manfaatnya adalah zat likopen dan sitrulin. Likopen merupakan antioksidan yang penting dalam meregenerasi sel kulit dan berfungsi untuk pengobatan beberapa jenis penyakit, salah satunya adalah diabetes mellitus. (Ardiyanti Y, dkk., 2015 dalam Yugo JP, 2017). Sama halnya dengan likopen, sitrulin juga zat antioksidan yang mempunyai peran dan efek baik untuk kesehatan (Ismayanti dkk, 2013).

Sebagai sumber protein nabatinya, minuman ini menggunakan sari kacang hijau sebagai pengganti sumber protein susu. Kandungan oligosakarida dan polisakarida pada kacang-kacangan berfungsi sebagai bahan energi untuk pertumbuhan BAL 
(Triyono, 2010). Berdasarkan beberapa hasil penelitian menyebutkan bahwa bahwa konsumsi kacang hijau menimbulkan flatulensi (gas) dalam perut. Flatulensi ini timbul karena adanya kandungan oligosakarida yang tidak dapat dicerna dan kemudian difermentasikan oleh bakteri usus. Kelebihan dari sari kacang hijau adalah rendah kandungan lemaknya sehingga bahan makanan/minuman yang terbuat dari kacang hijau tidak mudah tengik.

Sebagai sumber glukosa alami pengganti penggunaan gula, dilakukan penambahan sari kurma. Beberapa manfaat yang diharapkan dari penambahan sari kurma pada minuman fruitghurt ini adalah dapat memperbaiki sifat organoleptik dan gizi fruitghurt terutama protein nabati. Sebagaimana penelitian yang dilakukan oleh Imamah (2017), bahwa penambahan sari kurma berpengaruh terhadap muru organoleptik, viskositas, dan sineresis serta pada konsentrasi $40 \%$ memperbaiki kadar protein yogurt. Berdasarkan latar belakang di atas, penelitian ini dilakukan bertujuan untuk meningkatkan nilai nutrisi minuman probiotik fruitghurt dan untuk mengetahui karakteristik dari minuman probiotik tersebut.

\section{METODOLOGI}

\subsection{Waktu dan Tempat Penelitian}

Penelitian ini dilaksanakan di Laboratorium Teknologi Hasil Pertanian dan dilaksanakan penelitian pada bulan Maret 2019.

\subsection{Alat dan Bahan}

Peralatan yang digunakan pada penelitian ini yaitu panci, pengaduk kayu, kompor, timbangan, saringan, refrigerator, erlenmeyer, baker glass, laminar air flow, $\mathrm{pH}$ meter, viscotester incubator, ice cream cup, aluminium foil, wadah fermentasi, dan alat-alat untuk analisislaminar air flow, $\mathrm{pH}$ meter, viscotester incubator, ice cream cup, aluminium foil, wadah fermentasi, dan alat analisis. Adapun bahanbshsnnya adalah kulit semangka, kacang hijau, susu skim, starter plan, ekstrak kurma, air, dan bahanbahan kimia untuk analisis.

\subsection{Metode Penelitian}

Metode yang digunakan pada penelitian ini adalah menggunakan metode Rancangan Acak Lengkap (RAL) dengan tiga jenis perlakuan yaitu konsentrasi ekstrak kurma dengan yaitu $\mathrm{S}_{1}=5 \%$, $\mathrm{S}_{2}=15 \%, \mathrm{~S}_{3}=25 \%$. Data yang diperoleh kemudian diolah dan dianalisis menggunakan uji analisa sidik ragam untuk melihat pengaruh dari tiga jenis perlakuan dan akan dilakukan uji lanjut apabila terlihat pengaruh nyata dari perlakuan yang diberikan.

\subsection{Prosedur Kerja} berikut :

Adapun prosedur penelitian ini adalah sebagai

Tahap 1.Pembuatan Sari Kacang hijau
Kacang hijau dicuci sampai bersih, kemudian direndam selama empat jam, ditiriskan dan kacang hijau dicuci bersih sampai kesat (licin pada permukaan kulit hilang). Setelah itu, direbus kacang hijau hingga tekstur lunak. Kacang hijau yang telah lunak diblender, kemudian tambahkan air dengan perbandingan 1:2 dan peras sarinya. Hasil perasan (ekstrak kacang hijau).

\section{Tahap 2. Pembuatan Filtrat Kulit Semangka}

Kulit semangka yang telah dicuci dengan air bersih dipotong-potong kecil dan dihaluskan menggunakan blender. Setelah itu menyaring dengan kain penyaring. Filtrat tersebut kemudian dididihkan diatas kompor, didinginkan dan filtrat disaring kembali untuk menghilangkan endapan yang masing tersisa.

Tahap 3. Fermentasi

Hasil kedua filtrat yaitu sari kacang hijau dan filtrat kulit semangka ditambahkan susu skim dan dimixer kemudian ditambahkan ekstrak kurma (sesuai perlakuan) kemudian dinginkan. Setelah itu difermentasi. Memasukkan inokulum dengan starter yogurt plan (biakan bifidobacterium) sebanyak 0,5\% dan diinkubasi pada incubator dengan suhu $37^{\circ} \mathrm{C}$ dan selama 6 jam. Setelah inkubasi, minuman fruitgurt diaduk untuk homogenisasi dan dikemas dalam cup.

\subsection{Parameter Pengamatan}

Adapun Parameter pada penelitian ini adalah : kadar vitamin $\mathrm{C}$, kadar protein, total asam laktat.

\subsection{Prosedur Analisa}

\subsubsection{Kadar Vitamin C (Apriyantono dkk,1989)}

Untuk menganalisa kadar vitamin C pada minuman fruitghurt dilakukan dengan menggunakan metode titrasi iodin. Adapun prosedur kerja penentuan kadar vitamin C sebagai berikut :

Diambil 125 g yogurt, kemudian ambil $20 \mathrm{ml}$ lalu masukkan ke dalam labu takar $100 \mathrm{ml}$. Ditambahkan aquades sampai $100 \mathrm{ml}$ dan dipisahkan filtratnya dengan kertas saring. Filtrat diambil sebanyak $5 \mathrm{ml}$ dengan pipet lalu dimasukkan ke dalam erlenmeyer $125 \mathrm{ml}$. Kemudian ditambahkan 2 $\mathrm{ml}$ larutan amilum $1 \%$ dan dititrasi dengan $0,01 \mathrm{~N}$ standar iodin sampai larutan berwarna biru.

$\%$ Vitamin $C=\frac{m l \text { iod } \times 0,88 \times \mathrm{fp}}{\text { Berat bahan } \times 1000} \times 100 \%$

\subsubsection{Kadar Protein (Apriyantono dkk,1989)}

Ditimbang cuplikan sebanyak 0,1-0,5 gram, kemudian dimasukkan ke dalam labu kjeldahl yang berukuran $100 \mathrm{ml}$. Ditambahkan $25 \mathrm{ml} \mathrm{H} 2 \mathrm{SO} 4$ pekat dan 1 tablet kjeldahl. Dipanaskan di atas pemanas listrik atau api pembakar sampai mendidih dan larutan berubah menjadi jernih kehijauan-hijauan (sekitar 2 jam). Larutan dibiarkan dingin, kemudian diencerkan dan dimasukkan ke dalam labu ukur 100 
$\mathrm{ml}$, sampai tepat pada tanda garis. Pipet $5 \mathrm{ml}$ larutan dan dimasukkan ke dalam alat penyuling, ditambahkan $5 \mathrm{ml} \mathrm{NaOH} \mathrm{30 \%} \mathrm{dan} \mathrm{beberapa} \mathrm{larutan}$ indikator PP. Disuling selama 10 menit, sebagai penampung gunakan $10 \mathrm{ml}$ larutan asam borat $2 \%$ yang telah dicampur indikator. Ujung pendingin dibilas dengan air suling, dititrasi dengan larutan $\mathrm{HCl}$ $0,01 \mathrm{~N}$.

Kadar protein $(\%)$

$=\underline{\mathrm{V} 1-\mathrm{V} 2 \text { X N X 0,014 X fk X fp }} \times 100 \%$

\subsubsection{Total Asam Laktat (Apriyantono dkk, 1989)}

Prosedur analisa total asam laktat yaitu sampel sebanyak $5 \mathrm{ml}$ dimasukkan ke dalam labu takar kemudian dilakukan pengenceran dengan aquades sampai tanda tera. Kemudian, sebanyak 10 $\mathrm{ml}$ sampel dimasukkan ke dalam erlenmeyer, dan diberikan tambahan 3 tetes indikator phenolphtalein 1\%. Sampel dititrasi dengan larutan $\mathrm{NaOH} 0.1 \mathrm{~N}$ yang telah distandardisasi sampai terbentuk warna merah muda. Untuk menghitung TAT dapat dilakukan dengan rumus berikut:

TAT (\%) Asam Lakt $=\frac{v \times n \times 90 \times F P \times 100 \%}{w \times 1000}$

\section{HASIL DAN PEMBAHASAN}

3.1. Kadar Vitamin C Fruitgurt

Hasil analisa sidik ragam dan uji BNT fruitghurt dapat dilihat pada Tabel 1 sebagai berikut.

Tabel 1. Hasil analisis sidik ragam dan uji lanjut BNT kadar

\begin{tabular}{lll} 
& vitamin C & \\
\hline Perlakuan & Rata-Rata & Notasi \\
\hline $\mathrm{S}_{1}$ & 6.70 & $\mathrm{~b}$ \\
$\mathrm{~S}_{2}$ & 5.82 & $\mathrm{a}$ \\
$\mathrm{S}_{3}$ & 6.99 & bc
\end{tabular}

Sumber : Data Sekunder, 2020

Tabel 1 di atas menunjukkan bahwa perlakuan penambahan ekstrak kurma dengan konsentrasi yang berbeda menghasilkan kadar vitamin $\mathrm{C}$ fruitghurt yang berbeda-beda pula. Kadar vitamin $\mathrm{C}$ secara berturut dari yang terendah tertinggi adalah fruitghurt perlakuan $\mathrm{S}_{2}, \mathrm{~S}_{1}$, dan $\mathrm{S}_{3}$. Dengan kadar protein tertinggi pada perlakuan $\mathrm{S}_{3}$ yaitu penambahan ekstrak kurma $25 \%$ sebesar $6,99 \%$. Hasil analisis sidik ragam menunjukkan penambahan ekstrak kurma dengan konsentrasi berbeda memberikan pengaruh nyata pada $(\alpha=0,05$ dan $\alpha=0,01)$ terhadap kadar vitamin $C$ fruitghurt yang diihasilkan. Selanjutnya hasil uji lanjut BNT menunjukkan perlakuan $\mathrm{S}_{3}$ tidak berbeda nyata dengan perlakuan $\mathrm{S}_{1}$ namun berbeda nyata dengan $\mathrm{S}_{2}$. Hal ini dipengaruhi oleh konsentrasi ekstrak kurma yang ditambahkan lebih tinggi dibandingkan dengan perlakuan lainnya. Selain itu, juga disebabkan oleh kandungan vitamin $\mathrm{C}$ yang terkandung dalam kulit putih semangka dan sari kacang hijau.

\subsection{Kadar Protein Fruitgurt}

Perhitungan analisis sidik ragam dan uji lanjut BNT pada fruitghurt ditunjukkan oleh Tabel 2 berikut.

Tabel 2. Hasil analisis sidik ragam dan uji lanjut BNT kadar

\begin{tabular}{lcl}
\hline \multicolumn{3}{c}{ protein } \\
\hline Perlakuan & Rata-Rata & Notasi \\
\hline $\mathrm{S}_{1}$ & 7.75 & $\mathrm{~b}$ \\
$\mathrm{~S}_{2}$ & 4.57 & $\mathrm{a}$ \\
$\mathrm{S}_{3}$ & 9.60 & $\mathrm{c}$ \\
\hline
\end{tabular}

Sumber : Data Sekunder, 2020

Pada Tabel 2 di atas terlihat bahwa kadar protein secara berturut dari yang terendah-tertinggi adalah fruitghurt perlakuan $\mathrm{S}_{2}, \mathrm{~S}_{1}$, dan $\mathrm{S}_{3}$. Dengan kadar protein tertinggi pada perlakuan $\mathrm{S}_{3}$ yaitu penambahan ekstrak kurma 25\% sebesar 9,70\%. Kadar protein pada masing-masing perlakuan berbeda karena perbedaan konsentrasi penambahan ekstrak kurma. Hasil analisis sidik ragam menunjukkan bahwa masing-masing perlakuan memberikan pengaruh sangat nyata terhadap kadar protein fruitghurt $(\alpha=0,05$ dan $\alpha=0,01)$. Selanjutnya hasil uji lanjut BNT diperoleh bahwa $\mathrm{S}_{3}$ sangat berbeda nyata terhadap masing-masing perlakuan lainnya. Kadar protein fruitghurt bersumber dari protein bahan yang digunakan yaitu dari sari kacang hijau, kulit putih semangka, konsentrasi ekstrak kurma. Al Farsi dan Lee (2008), menyatakan bahwa kadar zat gizi yang terkandung dalam buah kurma antara lain karbohidrat, protein, lemak, 17 asam amino, serat, senyawa karetoneid, dll. Selain itu, kadar protein pada fruitghurt juga karena hasil dari aktivitas bakteri asam laktat.

Pada saat proses fermentasi oleh bakteri starter yang menghasilkan enzim protease, menghidrolisis protein pada susu dan kacang hijau terhidrolisis menjadi polipeptida dan asam amino. Dalam hal ini bakteri BAL merupakan bakteri dengan aktivitas proteolitik yang tinggi (Tarboush, 1995).

\subsection{Kadar Total Asam}

Hasil analisis rata-rata kadar total asam laktat terhadap fruitghurt ditunjukkan pada Tabel 3 berikut.

Tabel 3. Hasil analisis sidik ragam dan uji lanjut BNT kadar

\begin{tabular}{lll}
\multicolumn{2}{c}{ Total Asam } \\
\hline Perlakuan & Rata-Rata & Notasi \\
\hline $\mathrm{S}_{1}$ & 7.75 & $\mathrm{~b}$ \\
$\mathrm{~S}_{2}$ & 4.57 & $\mathrm{a}$ \\
$\mathrm{S}_{3}$ & 9.60 & $\mathrm{c}$ \\
\hline
\end{tabular}

Sumber : Data Sekunder, 2020 
Tabel 3 di atas menunjukkan kadar total asam fruitghurt setiap perlakuan berbeda-beda dengan kadar total asam laktat terbaik pada fruitghurt dengan penambahan ekstrak kurma $15 \%\left(\mathrm{~S}_{2}\right)$ yaitu sebesar 4,57\%. Hasil analisis sidik ragam kadar asam laktat diperoleh perlakuan memberikan pengaruh nyata terhadap kadar TAT fruitghurt $(\alpha=0,05)$. Hasil uji lanjut diperoleh bahwa perlakuan $\mathrm{S}_{3}$ berbeda nyata dengan perlakuan $S_{1}$ dan $S_{2}$. Perbedaan pada setiap perlakukan menunjukkan peningkatan nilai $\mathrm{pH}$ dipengaruhi oleh kadar $\mathrm{pH}$ yang dihasilkan selama proses fermentasi susu dengan kultur bakteri asam laktat. Meningkatnya $\mathrm{pH}$ yoghurt akan mengakibatkan terhambatnya kemampuan BAL dalam mendegradasi sukrosa menjadi asam laktat sehingga menyebabkan dimetabolisir yang menyebabkan $\mathrm{pH}$ akan meningkat (Syaputra, 2015). Tingginya kandungan asam-asam organik yang terbentuk dan kemudian terdisosiasi dalam bentuk ion-ion $\mathrm{H}+$ juga semakin banyak sehingga nilai pHcyang terukur oleh elektroda $\mathrm{pH}$ meter semakin menurun.

\section{KESIMPULAN DAN SARAN}

Kesimpulan yang dapat diperoleh berdasarkan hasil penelitian bahwa penambahan ekstrak kurma memberikan pengaruh nyata terhadap karakteristik gizi fruitghurt yang dihasilkan baik pada kadar vitamin C (S3 yaitu 6,99\%), kadar protein (S3 yaitu $9,60 \%$ ) dan kadar total asam (S2 yaitu 4,57). Karakteristik gizi fruitghurt terbaik berdasarkan kadar tertinggi baik vitamin $\mathrm{C}$, kadar protein adalah dengan penambahan ekstrak kurma 25\% $\left(\mathrm{S}_{3}\right)$. Dan berdasarkan kadar total asam laktat terbaik pada perlakuan $\mathrm{S}_{2}$ yaitu 4,57 .

\section{DAFTAR PUSTAKA}

Al-Farsi, M.A. dan Lee, C. Y. (2008). Nutritional and Functional Properties of Dates A Review. Critical Reviews in Food Science and Nutrition, Hlm. 48 (10).

Anjani S. (2013). Pengaruh Proporsi Kulit Semangka dan Tomat terhadap Hasil Jadi Masker Wajah Berbahan Dasar Tepung Beras. E-Journal, 02(3) : 22-26.

Apiyantono, A., D. Fardiaz, P. Niluh, S. Yasni dan S. Budiyanto. 1989. Petunjuk Laboratorium Analisis Pangan. IPB Press, Bogor.

Ardiyawati Y, Fithriyah NH. (2015). Pengaruh Waktu Inkubasi Terhadap Kadar Asam Laktat dalam Pembuatan Fruithgurt dari Kulit Buah Semangka. Seminar Nasional Sains dan Teknologi 2015 Fakultas Teknik Universitas Muhammadiyah Jakarta, 1-5.
Dillah, Shohib Qomad., Ismail., Abdul Malik Hosyiyar Rahman Yudha Pradipta Putra., Marisa Seravina. (2006). Pembuatan Susu Kacang Hijau Sebagai Alternatif Minuman Kesehatan. (pdf). Bogor : Institut Pertanian Bogor

Imamah, Irakhusnul. (2017). Pengaruh Konsentrasi Penambahan Sari Kurma (Phoenix Dactylifera L.) pada Pembuatan Yogurt Drink Ditinjau dari Mutu Organolpetik, Viskositas, Sineresis dan Kadar Protein. Thesis. Universitas Brawijaya, Malang.

Ismayanti, Syaiful Bahri, dan Nurhaeni. (2013). Kajian Kadar Fenolat Jus Kulit Buah Semangka. Online Jurnal of Natural Science, 2(3): 100-110.

Muslimah, R. (2010). Uji Organoleptik Fruitghurt Hasil Fermentasi Limbah Buah Anggur (Vitis vinifera) Oleh Lactobacillus bulgaricus. Skripsi. Surakarta: FKIP UMS.

Nusa MI, Misril F, Surya S. (2014). Studi Pembuatan Manisan Kering Kulit Buah Semangka (Citrullus lanatus). Agrium., 18(3) : 243- 249.

Syaputra, A., Pato, U., \& Rossi, E. (2015). Variasi penambahan sukrosa terhadap mutu cocoghurt menggunakan Enterococcus faecalis UP-11 yang diisolasi dari tempoyak. Jurnal Online Mahasiswa (JOM) Bidang Pertanian, 2(1), 1-11.

Tamime, A. Y. dan R. K. Robinson. (2007). Tamime and Robinson's Yoghurt Science and Technology (third edition). Cambridge England: Woodhead Publishing Limited.

Tarboush, A. H. M. (1995). Comparison of Associative Growth and Proteoliytic Activity Yogurt Starters in Whole Milk from Camels and Cows. J. Dairy Sci., 79 : 366-371.

Tiommanisyah. (2010). Analisa Kadar Protein Kasar Dalam Kacang Kedelai, Kacang Tanah dan Kacang Hijau Menggunakan Metode Makro Kjeldhal Sebagai Bahan Makanan Campuran. Fak. Mat. dan Ilmu Pengetah. Alam Univ. Sumatera Utara.

Triyono, A. (2010). Mempelajari Pengaruh Maltodekstrin dan Susu Skim Terhadap Karakteristik Yoghurt Kacang Hijau (Phaseolus radiatus L.). Jurnal Rekayasa Kimia dan Proses, 1411-4216. 
Yoga JP, Zanu H, Kun H. (2014). Pembuatan Yogurt Kulit Semangka dengan Pemanis Stevia dan Uji Sifat Kimia-Fisika. Jurnal University Reseach Colloquim (URECOL), 6, 171-176. 